\title{
The Effect of Principal Leadership Behavior, Teacher Model, and School Culture on Student' Character in Adapting to the Global Environment
}

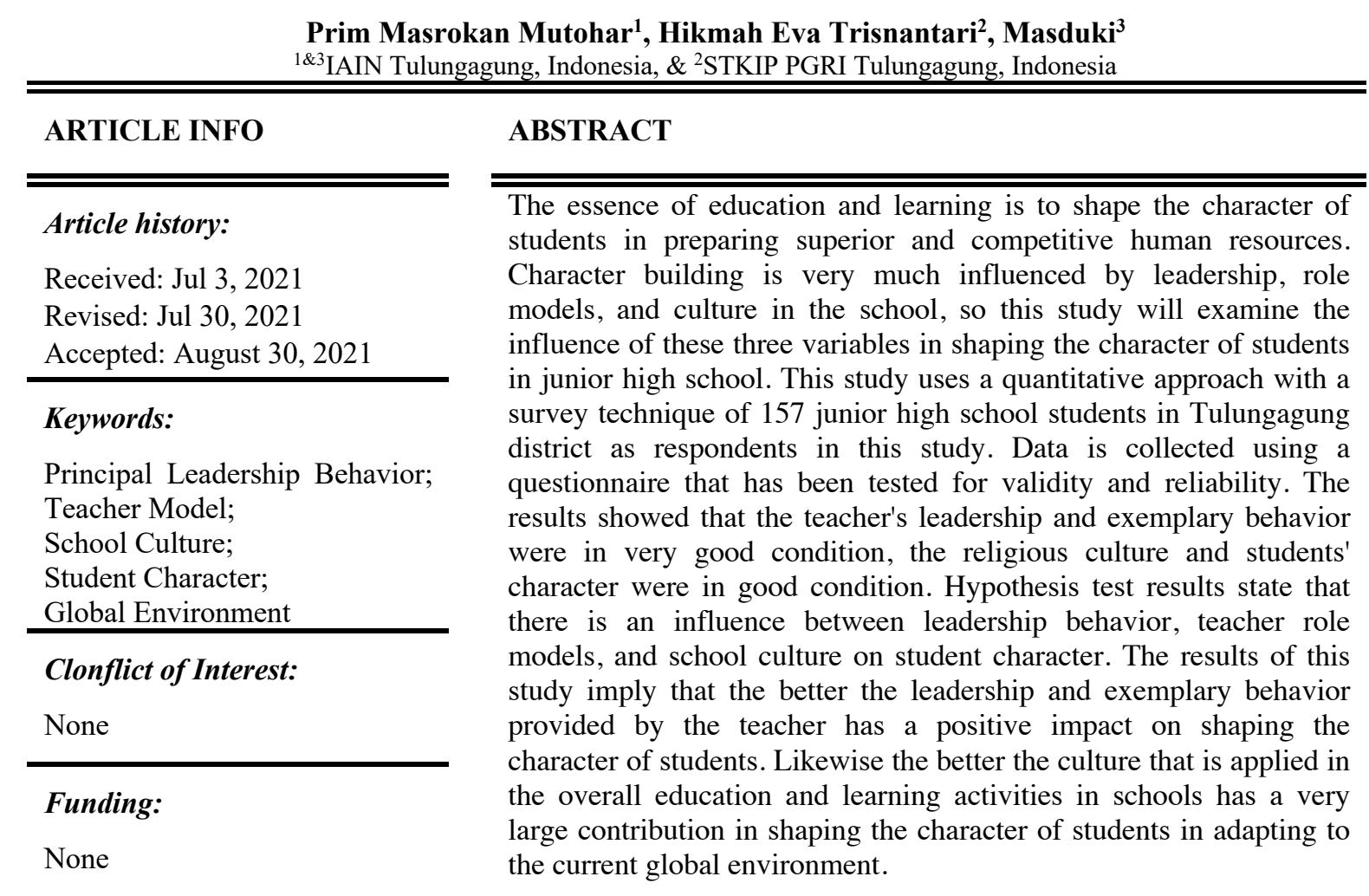

Corresponding Author: Prim Masrokan Mutohar, Graduate Program, IAIN Tulungagung, Tulungagung, Indonesia, E-mail: Pmutohar@gmail.com

(C) (O) This is an open access article under the CC BY-SA 4.0 international license.

1. Introduction

Character is highly needed in preparing superior human resources to be able to adapt to the current global environment. Education not only provides intellectual abilities and skills to students but must also be able to provide students with behavioral provisions so that they can adapt to social and work environments that are full of challenges and competition. Challenges and competition are continuously increasing and increasing in the current situation and conditions in the global environment. This condition must be responded positively by the school in preparing students to have personal and interpersonal competence ${ }^{[i]}$. Personal competence can be used as a basis for preparing professional human resources. This interpersonal or relational

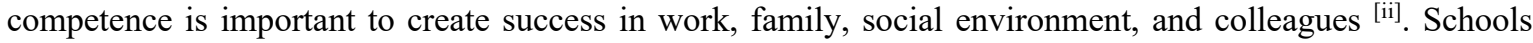
have duties and responsibilities to prepare students to have personal and interpersonal competencies or students have good and superior character. Character and behavior are very needed in adapting to the social environment of the community, work environment, family environment, and the national and state environment. School culture related to the actualization of behavior, traditions, daily habits, and symbols of school organization practiced by all school members, and the community around the school based on agreed values and being a school policy can play a role in creating successful character education in school ${ }^{\text {[iii] }}$. The development of outstanding school culture can shape the character of students so they can work hard in 
achieving success ${ }^{[i v]}$. This shows that the character of students needs to be prepared through education and learning in schools well, planned, and there are efforts to make improvements continuously. Character education can be integrated into the whole learning process in the classroom and outside the classroom. The principal has a very important role in character education in schools. Principal's leadership behavior, teacher's example, and school culture can influence the behavior of students who can continuously shape the character of students through the learning process directly or indirectly at school. The principal's leadership behavior strongly influences the character of students ${ }^{[\mathrm{v}]}$. Principals as policymakers can develop character education programs by including character education in the school curriculum ${ }^{[\mathrm{vi}]}$. The explanation proves that the principal's leadership behavior can create success or failure in the implementation of education and learning character in schools. Principals who have a high commitment and focus on goals can run school programs well. The running of the school program can prevent students from achieving success. The success achieved by students in attending education and learning is the responsibility of the principal and teachers. Therefore, the quality of learning must be improved continuously so that students can achieve the goals and quality standards that have been set. Principals as leaders and educators must be able to carry out their roles, tasks, and responsibilities in carrying out continuous innovations in improving the quality of education in schools. This quality improvement is not only related to academics but also related to social competencies that must be possessed by students. Social competence or social character of students can deliver students can carry out interpersonal relationships well. This interpersonal relationship is needed by students to be able to establish communication between individuals and between groups in the social environment and the work environment in the future. The success of a leader including the leadership of the principal in carrying out the tasks and

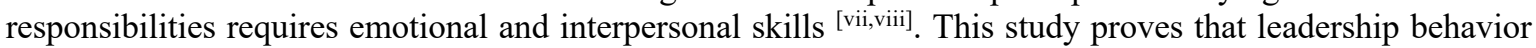
in school organizations influences the formation of social character that must be possessed by students in carrying out the whole process of education and learning in school. The teacher's behavior is also very influential in shaping the character of students in the school because the teacher as an educator must be able to provide examples of good behavior so that it can be imitated by students in the whole learning process at school ${ }^{[\mathrm{ix}]}$. The task and responsibility of the teacher are to teach students and also train students to be able to carry out ethical values to have good morals or character in social life ${ }^{[\mathrm{x}, \mathrm{xi}]}$. The role and task of the teacher as an educator has a very strategic function in teaching students to succeed in overall learning activities that are characterized by mastery of academic and non-academic competencies as well as good student character. Successful teachers have good behavior and set an example for students to live the ethical values that exist in the school. The teacher's behavior is modeled by all students in the school. The teacher's behavior is modeled by all students in the school. If the teacher runs the discipline well, then the students model the discipline taught by the teacher. This socially emotional behavior can easily influence the behavior of students in the learning process at school. Good behavior that is carried out continuously can be an effective school culture. Strong school culture is needed by each school to unite and build the commitment of the entire academic community in realizing school goals effectively and efficiently. Effective school culture can influence the entire learning process at school, including the formation of student character. School culture has a significant influence on student behavior and character formation ${ }^{[x i i]}$. The development of independent culture in solving problems, working in groups, a fun learning system can shape student character and provide life skills in exploring knowledge and behavior in daily life [xiii]. The integration of the values of honesty, discipline, clean living, healthy, tolerance, and work ethic in religious and cultural activities can influence student behavior [xiv]. The implementation of character values in learning can be included in the school curriculum and extracurricular so that it can systematically teach students to behave well in daily life in the school environment, family environment, and community environment ${ }^{[\mathrm{xv}]}$. This shows that the school culture that is implemented effectively can shape student behavior by the ethical values that are developed and implemented in schools continuously throughout the whole learning. This study will examine the effect of school principals' leadership behavior, teacher behavior, and school culture on the formation of student characters in schools in adapting to the global environment.

\section{Research Method}

This research is a quantitative study using a path analysis research design. Path analysis is used in this study to estimate the magnitude of the causal relationship of several research variables and the hierarchy of each variable in a series of direct or indirect causal relationships ${ }^{[\mathrm{xvi}]}$. Regression stages are used to analyze the strength of the influence of exogenous variables on endogenous that exist in this research model ${ }^{[\mathrm{xvii} x \mathrm{xiii}]}$ Endogenous variables are variables whose existence is influenced by other variables, while exogenous variables are variables whose existence is not affected by other variables in one research model ${ }^{[\mathrm{xix}, \mathrm{xx}, \mathrm{xxi}]}$. The relationship analysis model in this study has three relationship situations, namely: The first block about the principal's leadership behavior becomes an exogenous variable, and the teacher's model as an endogenous variable. In the second block, the principal's leadership behavior and teacher modeling are used as exogenous variables, while school culture is an

ASHREJ Vol. 3, No. 2, 2021: $36-44$ 
endogenous variable. The third block as an exogenous variable is the principal's leadership behavior, teacher model, and school culture, while the character of students is an endogenous variable. The research data were collected using a questionnaire that has been tested for validity and reliability. The questionnaire was filled by 150 junior high school student respondents in Tulungagung, East Java, Indonesia. The collected data were analyzed using descriptive statistics and multiple regression to determine the relationship between the research variables in each block of the path analysis design relationship. Descriptive analysis techniques are used to describe the condition of each research variable, while the multiple regression analysis techniques are used to determine the effect of exogenous variables on endogenous variables designed in this study. Besides that, the multiple regression analysis techniques can also be known as the magnitude of the influence of the whole and each element of the independent variable on the dependent variable ${ }^{[\mathrm{xxii}]}$.

\section{Results and discussion}

Personal skills related to the mastery of science and social skills are taught to students so that they can behave by ethical values in life and uphold the truth of science. Ethical behavior is taught to students so that they have good character to be able to adapt well to the development of science and culture that occur in the global environment. The results of the descriptive analysis of the principals' leadership behavior, teacher modeling, school culture, and student character in adapting to the global environment can be explained in the form of a table as follows:

Table 1. Percentage Analysis Results for Research Variables

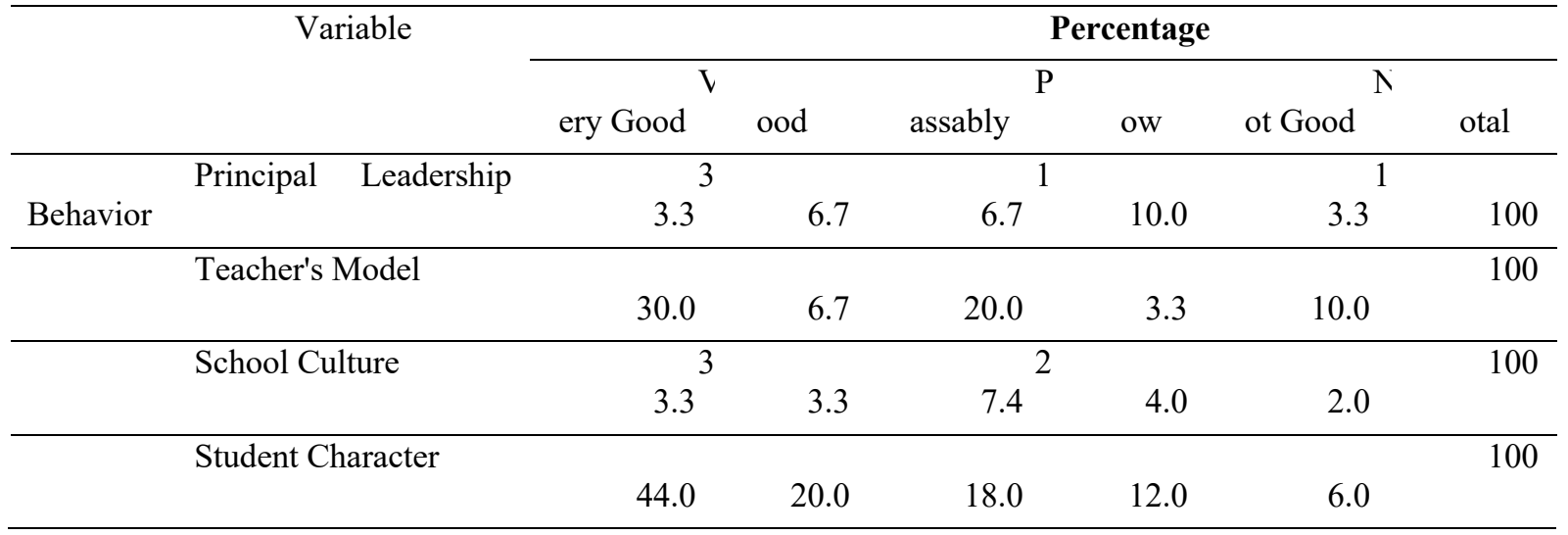

Based on the results of the analysis, it can be explained that the condition of each research variable shows that the leadership behavior of the principal is in very good condition with a percentage of $33.3 \%$, then continued with good condition with a percentage of $26.7 \%$, quite a good condition $16.7 \%$, and continued with bad condition $13.3 \%$, and $10 \%$ unfavorable condition. This shows that the principal's leadership behavior still needs to be continually improved to be better and no longer has bad or bad perceptions. The teacher's variable is in good condition with a percentage of $36.7 \%$ and continued with very good condition $30 \%$, quite a good condition $20 \%$, bad condition $10 \%$, and unfavorable condition $3.3 \%$. This shows that coaching to teachers can be done on an ongoing basis so that teachers can be the best role models for students in school and the life of society at large. School culture variables are in good condition and very good both get a percentage of $33.3 \%$, quite good $27.4 \%$, not good $4 \%$, and not good $2 \%$. The character of students is in very good condition by $40 \%$, good $20 \%$, good enough $18 \%$, and not good $6 \%$. The condition of each of these variables is interrelated with one another, therefore it is necessary to continually improve and improve principally the variables of principals' leadership behavior, teacher modeling, and school culture. Because these three variables are very influential in shaping the character of students in school.

\subsection{The Effects of Principal Leadership Behavior on Teacher's Model}

The results of block 1 path analysis can be explained that the coefficient of influence between the leadership behavior of the principal (X1) on the teacher's example (X2) is produced with a coefficient $b$ of $0.866, t$ of 4.825 , and $p$ (sig- $t$ ) of 0,000 . The results of this analysis can be concluded that the $p$-value is smaller than the 0.05 significance level so that the hypothesis stating there is no influence between the leadership behavior of the principal on the teacher's example is rejected, and it can be concluded that there is a significant influence between the leadership behavior of the principal with the role model teacher at Tulungagung Middle School. The coefficient of the dependent variable for the teacher exemplary variable $(\mathrm{P} 2 \mathrm{v})$ in this relationship path is 0.501 . This relationship path model can be seen in the picture as follows:

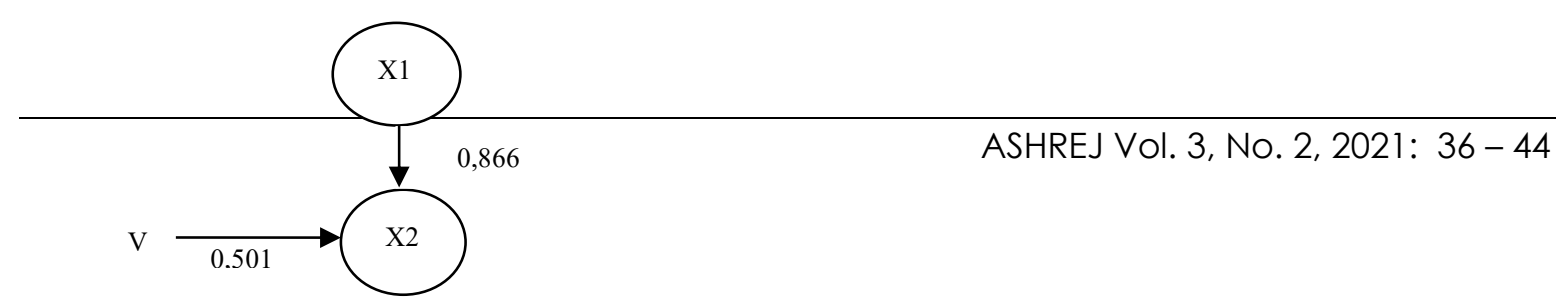


Figure 1. Hypothetical Model Pathway Influence Between Principals' Leadership Behaviors and Teacher Role Models

\subsection{The Effects of Principal Leadership Behavior and Teacher Model on School Culture}

The block II path model regarding the influence between principals 'leadership behavior and teacher's model on school culture in this study was formulated as follows: (1) there is no significant direct effect between the principals' leadership behaviors (X1) on school culture (X3), (2) there is no significant direct effect between teacher model (X2) on school culture (X3), (3) there is no indirect effect between the behavior of school principals (X1) and school culture (X3) through teacher modeling (X2) in schools. The results of block 2 path analysis can be explained that the direct effect coefficient between the principals' leadership behavior (X1) on school culture (X3) can be described with a coefficient $b$ of 0.187 , at the value of 2.464 , and a p (sig-t) of 0.015 . The results of this analysis indicate that $\mathrm{p}$ is smaller than the significance level of 0.05 . Based on the significance level it can be explained that the null hypothesis is rejected, so it can be concluded that there is a significant influence between the leadership behavior of the school principal and school culture. The coefficient of direct influence between teacher exemplary (X2) on school culture (X3) obtained results with a coefficient b of 0.722 , at a value of 9.538 , and $p$ (sig-t) of 0.000 . This shows that $p$ is smaller than the significance level of 0.05 . The results of this analysis indicate that the null hypothesis in this study is rejected, so it can be concluded that there is a direct influence between the leadership behavior of the principal on the culture of junior high schools in Tulungagung. The indirect effect between principals' leadership behavior (X1) and school culture (X3) through teacher model (X2) is calculated by multiplying P21 with P32, the results are as follows: P21 x $\mathrm{P} 32=0.866 \times 0.722=0.625$. The risk coefficient of the school culture-dependent variable (P3u) in the stage II relationship path obtained a value of 0.461 . The results of the analysis of this relationship path model can be seen in the picture as follows:

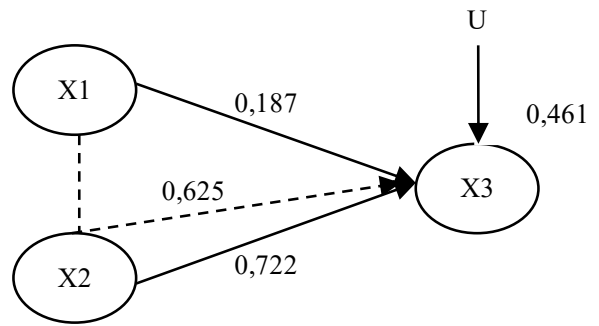

Figure 2. Correlation Coefficients on the Model of Relationships among Block II Variables

\subsection{The Effects of Principal Leadership Behavior, Teacher Model, and School Culture on Student Character}

The results of the path analysis in block III can be explained that the coefficient of direct influence between the principal leadership behavior (X1) on the character of students (Y) obtained the coefficient $b$ of $0.945, t$ value of 14.784, and $\mathrm{p}$ (sig-t) of 0,000 . This can be explained by the fact that $\mathrm{p}$ is smaller than the 0.05 significance level. Based on the 0.05 significance level, it explains that the null hypothesis which states there is no direct relationship between the leadership behavior of the principal and the student's character is rejected. Thus, it can be concluded that there is a direct effect between principals' leadership behavior with student characters. The coefficient of direct influence between the teacher's example (X2) on the student's character (Y) is depicted with a coefficient $b$ of 0.360 , at the value of 4.516 , and $p$ (sig-t) of 0,000 . This means that $p$ is smaller than the significance level of 0.05 . Based on these results it can be explained that the null hypothesis that has been formulated in this study was rejected, so it can be concluded that there is a significant direct effect between the teacher's example of the student's character. The coefficient of influence between school culture (X3) on student character (Y) obtained results expressed with a coefficient $b$ of 0.342 , $t$ value of 5.005 , and $\mathrm{p}$ (sig-t) of 0,000 . The results of this analysis indicate that $\mathrm{p}$ is smaller than the significance level of 0.05 . This condition can be explained that the null hypothesis about no influence between school culture and student character is rejected, so the results of this study provide conclusions that indicate the direct influence between school culture on student character. The coefficient of indirect effect between the principal's leadership behavior (X1) on the student's character (Y) through the teacher's example (X2) is calculated by multiplying P21 and Py2 with the following calculation: P21 x Py2 $=0.866 \times 0.945=0.818$. This calculation shows the existence of a path coefficient of 0.818 , this value is in a position greater than the significance level of 0.05 . The

ASHREJ Vol. 3, No. 2, 2021: $36-44$ 
research hypothesis which states there is no indirect effect between the behavior of school principals and student characters through exemplary teachers is rejected. Thus it can be concluded that there is a significant indirect effect between the leadership behavior of the principal and the character of students through the teacher model. The coefficient of indirect influence between the leadership behavior of the principal (X1) on the character of students (Y) through school culture (X3) is calculated by multiplying P31 and Py3 as follows: P31 x Py3 = $0.187 \times 0.342=0.064$. The results of the path coefficient indicate greater than a significance level of 0.05 , so it can be interpreted that there is an indirect effect between the leadership behavior of the principal and the character of students through school culture. The indirect coefficient of influence between the teacher's example (X2) and the student's character (Y) through school culture (X3) is calculated using P32 x Py3 = $0.722 \times 0.342$ $=0.247$. The results of this analysis indicate greater than the significance level of 0.05 , and it can be concluded that there is a significant indirect effect between teacher model and student character through junior high school culture in Tlungagung.

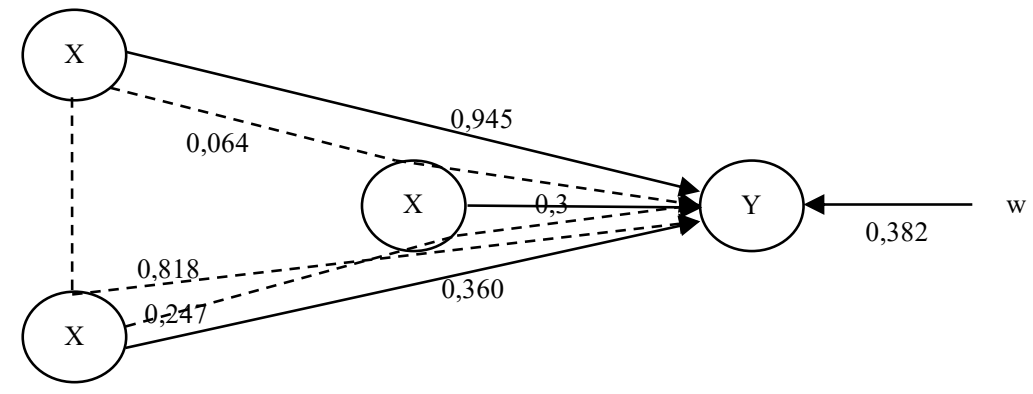

Figure 3. Correlation Coefficients in the Model of Relationships among Block III Variables

The global environment has delivered a variety of changes that occur very quickly. These changes and developments have an impact on the social environment in schools, families, and communities. Educational institutions as agents of change have the task and responsibility to prepare students to be able to face and participate in various developments that occur in the global environment. Students must be prepared so that they have a good character so they can adapt to facing changes and developments in global science and culture. The results showed that the strength of character has a very big influence on academic achievement ${ }^{\text {[xiii]. The }}$ formation of student character is inseparable from the role of the principal, the results of this study indicate that the behavior of the principal has a very strong influence on the formation of student character. The findings of this study are also strengthened by the results of the study which explains that the ethical leadership values applied by the principal can be a success in the character education program in schools ${ }^{[x x i v]}$. The principal acts as a motivator, creates a conducive climate, school culture, and becomes a good model in character education in schools ${ }^{[\mathrm{xxv}]}$. The results of this study and discussion explain that the principal's behavior as a leader is a major factor in realizing the successful implementation of character education in schools. The principal can mobilize all personnel and students in carrying out ethical behavior by the core values that are the policy of the school to be implemented in the school environment and the life of society at large. The success of character education in schools there are many that influence it, the findings of this study indicate that teachers have a very important role in shaping the character of students. The teacher has a strategic role in teaching students, students learn not only in class through the transfer of knowledge, but also can copy the teacher's behavior. Teachers as educators and mentors students must be able to make themselves good models for students because the results of this study found that teacher role models have a very strong influence on shaping student character. This finding strengthens the results of research that explain that teachers are role models for students, teachers as instructional leaders must show good behavior to be emulated by students ${ }^{[\mathrm{xxvi}]}$. Teacher behavior will be easily emulated by students, teacher behavior must be by ethical values that become core values in schools. This core value is more easily implemented by students if it is integrated with the values of local wisdom in the learning process ${ }^{[x x v i i]}$. Educational factors related to the quality of teachers in implementing the learning process are the most influential factors in character education in schools ${ }^{[x x v i i i]}$. Teachers become role models for students in character education at school, therefore teachers must have good character by the ethical values taught at school [xxix]. The ethical values in schools must be carried out continuously in the overall education and learning in schools to become a school culture. Strong and positive school culture can help schools achieve their vision and mission well. The results of this study indicate that the culture of this school can strongly influence the formation of student character. Ethical values, discipline, and responsibility that become student behavior in the learning and learning environment at school can help in achieving high learning achievement. The formation of students 'character can be achieved through the formation of school culture that is designed to apply behavioral values that will become students' moral excellence ${ }^{[\mathrm{xxx}]}$. The results of Samong, Suryadi, and Budimansyah's research ${ }^{[\mathrm{xxxi}]}$ explain that school culture influences developing character education. The research findings 
indicate that school culture is very effective in shaping student behavior. The principal has a major role in shaping the culture of the school-based on policies made in realizing the goals of the school effectively. Good principal leadership behavior influences the formation of a good school culture ${ }^{[\times x x i i]}$. The behavior of the principal can be an example for teachers, staff, and students. This directly or indirectly will affect the commitment of teachers, education staff, and students in carrying out the behavioral values that have been

carried out by the principal. Principal's leadership behavior has a strong influence on school culture ${ }^{[\mathrm{xxxiii}}$. The professionalism of teachers in carrying out their duties and responsibilities as educators can shape the school

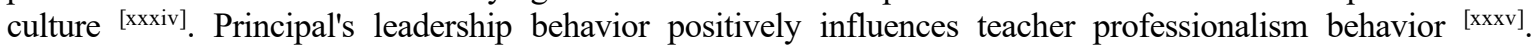
Principal leadership has a significant relationship with school culture ${ }^{[\mathrm{xxxvi}]}$. Good school culture can be used by principals as a medium to strengthen ethical behaviors that are the core values of schools and can also be used to influence and carry out their leadership tasks by building coordination between teachers and education personnel so that they have a direct impact on achievement student achievement ${ }^{[x x x v i i]}$. Principal's leadership behavior, teacher's example, and school culture have been shown to have a very strong influence on the character of students in school. This is because students can directly imitate these behaviors well. Students will grow and develop according to education and learning and the influence that exists in the social environment including the learning environment.

\section{Conclusion}

The global era that is happening at the moment is delivering the world community to adapt to rapid changes in all walks of life. Changes in the environment, culture, science, and technology must be responded positively by educational institutions to prepare students to be able to adapt to facing the global environment. This ability can be realized if students are trained continuously to have good character by the values and norms that are justified and recommended by religion, national culture, and ethical behavior in life. This condition can be realized well if there is a leadership behavior oriented to the principal of the principal to make it happen with full responsibility. The behavior of the principal can move the teacher to set an example for all students in the learning process at school. The examples set by teachers and principals in each learning environment can shape the school culture which can ultimately influence student behavior and shape student character by the vision, mission, and goals of the school in realizing student competence and good character. The results of this study have implications for the better leadership behavior of principals, teacher role models, and school culture, the better the character of students in the learning process at school. The improvement of the principal's leadership behavior, teacher's example, and school culture must be continuously improved so that character education can be successful. The success of character education can help in preparing human resources who can adapt to the development of science, technology, and the global environment.

\section{Reference}

Mutohar, P.M. Manajemen Pendidikan: Substansi Inti Pengelolaan Lembaga Pendidikan. Tulungagung: IAIN Tulungagung Press. 2017.

Hatcher, R. L., Interpersonal competencies: Responsiveness, technique, and training in psychotherapy. American Psychologist, 70(8), 747, 2015

Mutohar, Prim Masrokan. "Pengembangan Budaya Religius (Religious Culture) di Madrasah: Strategi Membentuk Karakter Bangsa Peserta Didik." Didaktika Religia 1.1, 2016.

Yuliono, Agus. "Pengembangan Budaya Sekolah Berprestasi: Studi tentang Penanaman Nilai dan Etos Berprestasi di SMA Karangturi." Komunitas: International Journal of Indonesian Society and Culture 3.2, 2011.

Suriansyah, Ahmad. "Strategi Kepemimpinan Kepala Sekolah, Guru, Orang Tua, dan Masyarakat dalam Membentuk Karakter Siswa." Jurnal Cakrawala Pendidikan 34.2, 2015.

Smith, Matthew R. "Contemporary Character Education." Principal Leadership 6.5 (2006): 16-20.

Riggio, Ronald E., and Joanne Lee. "Emotional and interpersonal competencies and leader development." Human Resource Management Review 17.4 (2007): 418-426.

Englefield, Eve, et al. "Interpersonal competencies define effective conservation leadership." Biological conservation 235 (2019): 18-26.

Demirel, Melek, Demet Özmat, and Imgehan Özkan Elgün. "Primary School Teachers' Perceptions about Character Education." Educational Research and Reviews 11.17 (2016): 1622-1633.

Lapsley, Daniel, and Ryan Woodbury. "Moral-character development for teacher education." Action in teacher education 38.3 (2016): 194-206. 
Blegur, Jusuf, Theodora SN Manu, and Mieke Souisa. "Students' disciplined character as the effort to improve self-esteem and academic performance." International Journal of Academic Research in Business and Social Sciences 8.4 (2018): 366-376.

Madya, S., and I. Ishartiwi. "Instilling character values through a local wisdom-based school culture: An Indonesian case study." Character Education for 21st Century Global Citizens 3 (2018): 371-380.

Daniati, Silvia Puspita. "Natural School Culture as a Free and Fun Alternative Education in Building the Students' Character." Elementary Education Online 18.1, 2019.

Marini, Arita. "Integration of character values in school culture at elementary schools in Jakarta, Indonesia." Journal of Arts \& Humanities 6.5 (2017): 21-32.

Mutohar, P.M., and Trisnantari, H.E. "Design of Character-Based Learning in Islamic Elementary Schools with a Full Day System." International Journal of Science and Research (IJSR). 9. 3, 2020.

Kerlinger, F.N. Behavioral Research. New York: Holt Rinehart \& Winston, 1985.

Muhidin, S. A. Analisis Korelasi, Regresi, dan Jalur alam Penelitian, Bandung: CV Pustaka Setia, 2007.

Riduwan, dan Engkos Achmad Kuncoro. 2017. Cara Menggunakan dan Memakai Path Analysis (Analisis Jalur). Bandung: Alfabeta

Asher, H.B. Causal Modeling. London: Sage Publication, 1983

Cohen, J., \& Cohen, P. Applied Multiple Regression/Correlation Analysis for the Behavioral Science. London: Lowrence Erlbaum Associated Publiser, 1983.

Cohen, D. Statistical Analysis. New York: Holt Rinehart and Winston Inc., 1983.

Hadi, Sutrisno. Analisis Regresi. Yogyakarta: Yayasan Penerbit Fakultas Psikologi UGM, 1986.

Tang, Xiaoqing, et al. "Character Strengths Lead to Satisfactory Educational Outcomes through Strengths Knowledge and Strengths Use." Frontiers in psychology 10 (2019): 1829.

Gunawan, Imam Imam, and Imam Gunawan. "Develop Educational Leadership by Applying Values and Ethics to Strengthen Student Character." 5th International Conference on Education and Technology (ICET 2019). Atlantis Press, 2019.

Juharyanto, Juharyanto, Ahmad Yusuf Sobri, and Ahmad Nurabadi. "The Principal Leadership in Strengthening Elementary School Education Character." 3rd International Conference on Educational Management and Administration (CoEMA 2018). Atlantis Press, 2018.

Gunawan, Imam Imam, and Imam Gunawan. "Develop Educational Leadership by Applying Values and Ethics to Strengthen Student Character." 5th International Conference on Education and Technology (ICET 2019). Atlantis Press, 2019.

Parwati, Ni Nyoman, I. Made Tegeh, and I. Made Mariawan. "Integrating the Values of Local Wisdom into the Learning Model: Building Positive Student Character." Educational Technology to Improve Quality and Access on a Global Scale. Springer, Cham, 2018. 297-307.

Gündoğdu, Kerim, et al. "Teachers' Views on Character/Values Education in Schools." International Journal of Psycho-Educational Sciences (2019): 14-28.

Demirel, Melek, Demet Özmat, and Imgehan Özkan Elgün. "Primary School Teachers' Perceptions about Character Education." Educational Research and Reviews 11.17 (2016): 1622-1633.

Kurniawati, Eni Kurniawati, and Sunarso Sunarso. "Forming Students' Character through School Culture in Senior High School Taruna Nusantara Magelang." Jurnal Ilmiah Peuradeun 7.1 (2019): 141-162.

Samong, Fransiskus, A. Suryadi, and Dasim Budimansyah. "The development of character education in primary schools through the enhancement of school culture." 1st UPI International Conference on Sociology Education. Atlantis Press, 2016.

Bennett, Tom. "Creating a Culture: How School Leaders Can Optimise Behaviour." UK Department for Education (2017).

Karada, Engin, and Ozge Öztekin. "The effect of authentic leadership on school culture: A structural equation model." International Journal of Educational Leadership and Management 6.1 (2018): 40-75.

Seashore Louis, Karen, and Moosung Lee. "Teachers' capacity for organizational learning: The effects of school culture and context." School Effectiveness and School Improvement 27.4 (2016): 534-556. 
Mitchell, Roxanne M., and C. John Tarter. "A path analysis of the effects of principal professional orientation towards leadership, professional teacher behavior, and school academic optimism on school reading achievement." Societies 6.1 (2016): 5.

Rampersad, Roydon. An analysis of principal leadership and its influence on school culture in two primary schools in Trinidad and Tobago. Diss. University of Leicester, 2018.

Lewis, Jennifer, et al. "The Best Practices for Shaping School Culture for Instructional Leaders." Alabama Journal of Educational Leadership 3 (2016): 57-63. 